\title{
A HISTÓRIA É PRISIONEIRA DA POLITICA
}

\author{
Ruy Nedel
}

Este pensamento é válido para a história de todos os povos, pois que nunca podemos dissociar uma da outra. Os homens públicos e a política participam da história, fazem história e entram na história, o que é comum a todos os povos. Entretanto, nesses casos, a política é mais uma ferramenta da história, conforme os dizeres de Mantilla e Salvador Cabral. A política, sob este raciocínio, é efetivamente um dos instrumentos pelos quais os povos, entre si e dentro de si, fazem suas histórias. Todavia, no caso específico das Missões Jesuiticas instaladas ao longo da Bacia do Prata nesta região sul-americana, mais do que em nenhum outro povo, a História foi PRISIONEIRA da Política.

I) Foi prisioneira permanente das políticas palacianas e nacionais de Portugal e Espanha e entre Espanha e Portugal. Esteve aprisionada às questões e crises religiosas dentro do Vaticano e deste com ordens e congregações religiosas, a ponto de termos um Papa eleito com a finalidade precípua de extinguir a Companhia de Jesus. Prisioneira contínua das crises do Vaticano com governos temporais até mesmo nas questões de navegação. Foi prisioneira das guerras e convulsões européias e as relações entre os países do Velho Continente. Quando a realeza de Portugal e Espanha festejavam entre si um casamento, ou através dele promoviam uma aliança, os índios missioneiros, em vez de festa, padeciam aqui, os efeitos negativos. A morte de alguém da realeza na península ibérica representava quase sempre alterações nas fronteiras de além-mar. A História Missioneira foi assim, torturada pelo açoite gigantesco que, vibrado pelos variados punhos europeus, surrava e vergastava as costas sul-americanas em sua nova formação histórica.

II) A História das Missões foi prisioneira da política dos povos dominadores de terras sul-americanas. Nunca thes foi permitido desenvolver com tranqüilidade a sua civilização fazendo a sua história com liberdade porque ao lado luso-brasileiro houve sempre a voracidade opressora escravagista do bandeirante. Até mesmo a geografia foi aziaga às missões, pois fazendo o Rio 
Tietê membro da Bacia do Prata em vez de correr direto à Costa Atlântica do Planalto de Piratininga para Santos, estimulou a tenacidade desbravadora do bandeirante em busca de escravos agrupados nas Reduções Jesuíticas.

A ganância portuguesa e do Brasil Império em dilatar as fronteiras até a boca do Prata e a oeste sempre de olhos voltados à mesopotâmia para que seus domínios atingissem o Rio Paraná, foi um fator de permanente opressão dificultando a formação histórica dos povos missioneiros, mesmo muito após os jesuitas.

Os encomenderos espanhóis ou de Assunción, Santa Fé, Corrientes, Entre-Rios, esmagavam o índio e bloqueavam as missões e sua história pelo lado ocidental procurando o uso e abuso do nativo para a formação de uma subraça como instrumento e usufruto da elite local.

Mais tarde, já na luta pela independência dos povos latino-americanos quando os índios missioneiros, liderados por Andrés Guacurari (Andresito Artigas) e os mestiços, criollos ou gaúchos liderados por José Artigas, novamente a história foi prisioneira da política dos dominadores autóctones, desta vez das elites comerciais e portuárias de Buenos Aires e Montevideo que não hesitaram em se aliar aos arqui-inimigos luso-brasileiros a fim de destruir a ferro e fogo o último grito e sonho de Pátria Missioneira dos antigos Povos das Missões Jesuíticas, mais uma vez unindo os interesses locais com os do continente europeu, repercutindo aqui negativamente o domínio da Inglaterra sobre a península ibérica, seus sucessos na Guerra Napoleônica e o resultado de Waterloo em 1815.

III) A história das missões jesuíticas foi prisioneira da política na sua redação de forma vilipendiada de acordo com a vontade dos governos e governantes variando conforme o lado da fronteira e ao sabor da oscilação da mesma, ou mesmo no tempo, conforme o interesse de um governo ou regime.

Esta realidade é dura e abjeta, porquanto, além de aprisioná-la, tortura a história, violentando-a em adulterações ignóbeis não só para o povo simples, também nas escolas e até nas universidades.

A título de falso patriotismo ela é mais mal contada ou ensinada para quem vive no meio da geografia em que se geraram os fatos, transformando verdades em mentiras, feitos épicos em fugas covardes, heróis passa a vilões, civilizações de alta disciplina e cultura passam a constar como barbárie ignara. $\mathrm{O}$ inverso é verdadeiro e a verdade se torna uma falácia. O conquistador se rotula como paradigma de civilizado; ao cometer os atos mais brutais, redige-os para a história como atos de heroismo em defesa de uma moral civilizada e civilizadora.

Chegamos ao ponto de no Rio Grande do Sul (epicentro brasileiro desta história, nascido e criado a partir do ocidente de tal modo que, ao ser instalado o Forte do Rio Grande em 1737, o coração do Continente já possuía ele- 
vada organização social, urbana, agro-pastoril e industrial), surgir um historiador decantado como Moysés Velhinho com visão totalmente fora da realidade histórica, interpretando Missões com extrema xenofobia e expondo em sua obra, agudo sentimento lusitanófilo, nem sequer brasileirista.

Quando em pleno século vinte surge historiador dessa estirpe não se pode estranhar o fato de que os novos povos ou mescla de povos a repovoar a região das missões jesuíticas não se apercebam da história aprisionada e destruam os patrimônios físicos deixados por uma raça ou civilização; seja para cultuar a mística que, apesar de tudo, persiste ou para construir seus prédios e novos templos; destruir para apagar lembranças e consciências, apesar de embotadas, sentindo o peso do crime histórico; seja por um intendente para afugentar morcegos como ocorreu na destruição do secular colégio do Povo de São Luiz Gonzaga; ou por um interventor de São Nicolau, como ainda há poucos anos, arrancando as pedras talhadas pelos índios missioneiros, para construir pontilhões no interior do município!

A história das Missões Jesuíticas continua prisioneira da política até mesmo no angustiado anseio pela verdade histórica porque, mesmo então, tende a ser escrita pelo lado e ótica do vencedor. Ao longo do tempo ela foi relatada e registrada pelo lado português e espanhol; brasileiro, argentino e paraguaio (?); pelo jesuíta, todavia, jamais pelo índio. Os Oberá e Nheçu, Neenguirus e Sepé Tiaraju entre tantos outros e todos os guaranis e tapes foram agentes desta HISTÓRIA, contudo não a historiaram.

A HISTÓRIA SE ESCREVE A PARTIR DO HOMEM e não do governo, seja de um país, de um imério, ou de uma comunidade. Por isso protestamos contra a visão e relato de Moysés Velhinho; este também é o motivo pelo qual repudiamos a redação historiada de Pe. Jaeger S.J. transcrevendo para a história um Nheçu feiticeiro demoníaco, maligno e fascínora, um Potiravá assassino e herege traidor entre outros guaranis das margens do Ijuí que se desconcertaram com a imposição brusca de uma nova fé contra milênios de outra cultura e organização. Mesmo as Ânuas dos jesuítas da época devem ser lidas, jamais como facciosos, no entanto, sob a ótica unilateral do missionário e não missioneiro; do governante e não do governado; do relator prestando contas a um poder maior, seja religioso (a Ordem da Companhia de Jesus e o Vaticano), seja um império (a Espenha, os Vice-Reis e Governadores).

Por isso a fidelidade histórica só poderá expressar a essência da verdade ao se amparar profundamente no estudo da ARQUEOLOGIA. Esta se ampara essencialmente no que fez o homem no micro ou macrocosmos social e a partir dele escreve ou descreve sem interferências de outros interesses.

Com esta nova visão o Rio Grande do Sul, através de suas Universidades da Capital, para o Brasil e pelo Brasil, deu um salto cultural e de fidelidade na história missioneira, não mais a redigindo sob o prisma do conquistador, 
mas a partir do povo ou indivíduo agente da história. Tendo em mãos a arma da arqueologia foram liquidados os preceitos e preconceitos sectários ou unilaterais para escrever-se esta história embasada na verdade ou na procura dela.

IV) Visão da Literatura:

A literatura, na forma do Romance Histórico, liberta a história e a interpreta. Liberta o indivíduo para a História, o indivíduo ator e o indivíduo leitor.

O historiador descreve o mundo coletivo de um povo ou sociedade, ou civilização. O escritor, através do romance, invade o mundo do indivíduo na sociedade em que vive. Não falseia a verdade histórica mesmo no abuso da imaginação fértil, porquanto, fugindo desta verdade avança no mundo individual avaliando as ações e reações deste que a história pura não pode descrever. Noutro plano, ao dar rédeas à imaginação e analisando o povo no qual está integrado o indivíduo, o autor o procede dentro dos preceitos da liberdade, interpretando os fatos podendo convencer ou não o leitor livre, ciente do raciocínio interpretativo.

$\mathrm{Na}$ história das Missões Jesuíticas o principal agente desta história - o índio, o vencido - não a escreveu; esta é uma razão forte, quase imperiosa, para que a literatura aumente seu espaço neste conteúdo histórico, porquanto só ela pode e tem o direito de interpretar os sentimentos do indivíduo ou grupo de individualidades (sociedade) dentro deste consenso triste, trágico e genocida, mas também impressionante e fantástico.

Foi o que o modesto autor de ESTA TERRA TEVE DONO tentou fazer. 